Utah State University

DigitalCommons@USU

$5-7-2008$

\title{
Particle Composition and Size Distributions in and Around a Deep- pit Swine Operation, Ames, IA
}

\author{
Randal S. Marin \\ Utah State University \\ Philip J. Silva \\ Kori Moore \\ Mark Erupe \\ Vishal S. Doshi
}

Follow this and additional works at: https://digitalcommons.usu.edu/sdl_pubs

\section{Recommended Citation \\ Marin, Randal S.; Silva, Philip J.; Moore, Kori; Erupe, Mark; and Doshi, Vishal S., "Particle Composition and Size Distributions in and Around a Deep-pit Swine Operation, Ames, IA" (2008). Space Dynamics Lab Publications. Paper 88. \\ https://digitalcommons.usu.edu/sdl_pubs/88}

This Article is brought to you for free and open access by the Space Dynamics Lab at DigitalCommons@USU. It has been accepted for inclusion in Space Dynamics Lab Publications by an authorized administrator of DigitalCommons@USU. For more information, please contact digitalcommons@usu.edu.

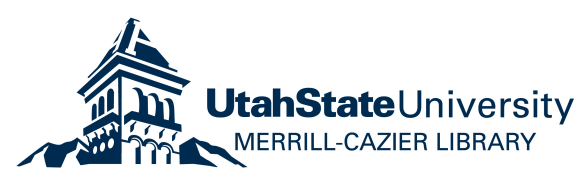




\title{
Particle composition and size distributions in and around a deep-pit swine operation, Ames, IA
}

\author{
Randal S. Martin • Philip J. Silva • Kori Moore • \\ Mark Erupe • Vishal S. Doshi
}

Received: 12 January 2007 / Accepted: 18 March 2008/Published online: 7 May 2008

(C) Springer Science + Business Media B.V. 2008

\begin{abstract}
The contribution of emissions from agricultural facilities is rapidly becoming a major concern for local and regional air quality. Characterization of particle properties such as physical size distribution and chemical composition can be valuable in understanding the processes contributing to emissions and ultimate fate of particulate matter from agricultural facilities. A measurement campaign was conducted at an Iowa, deep-pit, three-barn swine finishing facility to characterize near-source ambient particulate matter. Size-specific mass concentrations were determined using minivol samplers, with additional size distribution information obtain using optical particle counters. Particulate composition was determined via ion chromatographic analysis of the collected filters. A thermal- $\mathrm{CO}_{2}$ elemental/organic carbon analyzer measured particulate carbon. The chemical composition and size distribution of sub-micron particles were determined via real-time aerosol mass spectrometry. Primary particulate was not found to be a major emission from the examined facility, with filter-based impactor samples showing average near-source increases $(\sim 15-50 \mathrm{~m})$ in ambient $\mathrm{PM}_{10}$ of $5.8 \pm 2.9 \mu \mathrm{g} \mathrm{m}^{-3}$ above background levels. $\mathrm{PM}_{2.5}$ also showed contribution attributable to the facility $\left(1.7 \pm 1.1 \mu \mathrm{g} \mathrm{m}^{-3}\right)$. Optical particle counter analysis of the numerical size distributions showed bimodal distributions for both the upwind and downwind conditions, with maximums around $2.5 \mu \mathrm{m}$ and below the minimum quantified diameter of $0.3 \mu \mathrm{m}$. The distributions showed increased numbers of coarse particles $\left(\mathrm{PM}_{10}\right)$ during periods when wind transport came from the barns, but the differences were not statistically significant at the $95 \%$ confidence level. The $\mathrm{PM}_{10}$ aerosols showed statistically increased concentrations of sulfate, nitrate, ammonium, calcium, organic carbon, and elemental carbon when the samplers were downwind from the pig barns. Organic carbon was the major constituent of the barn-impacted particulate matter in both sub-micron (54\%) and coarse size $(20 \%)$ ranges. The AMS $\mathrm{PM}_{1}$ chemical speciation showed similar species increases, with the exception of $\mathrm{NO}_{3}^{-}$and $\mathrm{Ca}^{+2}$, the latter not quantified by the AMS.
\end{abstract}

Keywords Swine $\cdot$ Particles $\cdot \mathrm{PM}_{10} \cdot \mathrm{PM}_{2.5} \cdot$ Composition $\cdot$ Size distribution

R. S. Martin $(\bowtie) \cdot$ K. Moore $\cdot$ V. S. Doshi

Department of Civil \& Env. Engineering, Utah State University, Logan, UT 84322-4110, USA

e-mail: rmartin@cc.usu.edu

P. J. Silva $\cdot$ M. Erupe

Department of Chemistry \& Biochemistry, Utah State University, Logan, UT 84322-0300, USA 


\section{Introduction}

Agricultural operations are known to be sources of many types of particles and gases that can ultimately exhibit an influence on local and regional air quality. Emissions potentially impacting air quality from agricultural sources have become a concern for regulatory agencies such as the United States Department of Agriculture (USDA) and the United States Environmental Protection Agency (EPA; USDA 2006; U.S. EPA 2005a). In particular, particulate emissions and gas-phase precursors are of interest because of the implied health effects of particulate matter from epidemiological studies (e.g. Dockery 1993). Agricultural facilities are generally treated as area sources in emissions inventories, however emissions can vary depending on practices used from facility to facility. Particulate influences from agricultural sources can include both primary particles (direct dust-type or combustion emissions) and secondary particles (formed photochemically from gaseous precursors such as ammonia).

Several deficiencies exist for understanding agricultural sources that must be addressed before effective regulations and remediation practices can be implemented (Aneja et al. 2006; USDA 2006). The areas of deficiency include accurate particulate and gaseous emission factors relevant to operational practices, validation of accurate and precise instrumentation and measurement protocols, and establishment of educational and outreach programs to effectively transfer the most current information to all stake holders, including facility operators. Within the past few years, several studies have been implemented which focus on the development of relevant emission factors for confined animal feeding operations (CAFOs), most commonly targeting total suspended particulate (TSP), particulate matter less than or equal to 10 microns $(\mu \mathrm{m})$ in diameter $\left(\mathrm{PM}_{10}\right)$, and gasphase ammonia $\left(\mathrm{NH}_{3}\right.$; Wathes et al. 1997; Takai et al. 1998; Schmidt et al. 2002; Heber et al. 2005; Hoff et al. 2005 and others). Martin et al. (2006a, b) reported particulate matter less than or equal to $2.5 \mu \mathrm{m}$ in diameter $\left(\mathrm{PM}_{2.5}\right)$ emissions for swine and dairy operations.

Most of the currently available particulate emission algorithms for agricultural facilities focus only on total emissions, with little emphasis on particle composition and size distribution beyond base categorization (e.g. $\mathrm{PM}_{10}$ ). This may be due to the domination of coarse $(>5 \mu \mathrm{m})$ particulate emissions from typical agricultural facilities (Auvermann et al. 2006). However, near-source particles may undergo rapid physical and compositional changes which affect their size distribution (coagulation and nucleation) and base chemistry (secondary species formation) as they transport downwind from the source (Lammel et al. 2004). Physical and chemical properties of the anthropogenically produced aerosols near-source and in ambient environments have been widely studied (Rogge et al. 1993; Hughes et al. 1999; Turnbull and Harrison 2000; Alfaro and Laurent 2001; and others). Although some particulate size and mass distributions and their variabilities have been investigated for various livestock facilities like swine, poultry, dairy, etc. (e.g. Crichlow et al. 1980; Nilsson 1982; Müller and Wieser 1987; Speizer et al. 1988; Barber et al. 1991), these studies were primarily limited to inside facilities and their behavior upon exhaust into the ambient environment has not been sufficiently investigated. Lammel et al. (2004) quantified numerical size distribution of the particles 100-400 m from a German diverse livestock facility (pigs, cows and poultry) and found the tested facility strongly contributed an increased number of particles in the upper two observed size ranges (1-4 $\mu \mathrm{m}$ and $4-20 \mu \mathrm{m}), 1.7 \times-2.1 \times$ and $2.0 \times-6.4 \times$ above background, respectively. Lammel et al. (2004) reported that approximately $20 \%$ of the near-farm particulate material consisted of organic carbon (OC), but they were not certain statistically what fraction of OC originated from the facility. 
Characterization of the particle properties such as physical size distribution and chemical composition can be valuable in understanding the processes contributing to emissions of particulate matter from agricultural facilities. The study described was designed to characterize concentrations of particulate matter in the immediate vicinity of a deep-pit swine facility. In addition, characterization of particle mass and number distributions was obtained to determine relative contribution of the swine facility to fine and coarse particulates. The chemical composition of the detected particulate matter was also characterized.

A secondary purpose for the data acquired will be for validation and calibration of a Light Detection and Ranging (LiDAR) system developed by Utah State University's (USU's) Space Dynamics Laboratory (SDL). SDL's “AGLITE” LiDAR system, which has been developed for the measurement of particle emissions from agricultural facilities (Wilkerson et al. 2006), is an example of remote sensing instrumentation being developed to determine particulate emissions on finer temporal and wider spatial scales across an entire facility. Data for particle mass concentration and number density are used to calibrate the measurement of the LiDAR system. While the LiDAR can obtain real-time information about particle plumes from different locations within an area source, calibration of the signals to real mass concentrations obtained from point samplers is necessary. The use of the data described here for the calibration of the LiDAR is described in a separate report. (Zavyalov et al. 2006).

\section{Methodology}

\subsection{Site description}

The study described herein occurred from August 24 to September 8, 2005. The sampling site was a deep-pit, swine finishing operation located near Ames, Iowa, USA. The facility consisted of three parallel, east-west oriented barns. Each barn was approximately 80 meters $(\mathrm{m})$ long by $14 \mathrm{~m}$ wide, and housed around 1,250 pigs, each with an average animal weight of about 45.5 kilograms $(\mathrm{kg})$. The ventilation for each barn was primarily via passive air exchange by means of two large $79 \mathrm{~m}$ by $1.5 \mathrm{~m}$ curtain-controlled window openings on the north and south sides of each building. A graveled county road ran parallel to the south property line about $46 \mathrm{~m}$ from the southern most barn (Barn 1). The site layout and receptor/sampling locations are shown in Fig. 1.

The farm was surrounded by cultivated corn fields on the north and west sides and soybean fields on the east and south sides. Fields immediately adjacent to the facility were planted during the study period, with no harvesting or other activities taking place. Five years of historic climatological data were examined to determine the prevailing wind direction during the calendar sampling period and it was found that the expected wind was predominantly from the south (U.S. EPA 2005b). Samplers were placed at locations downwind of the facility given this wind assumption. A sampler in the beanfield was placed due east of the barns to serve as a representative background. On-site meteorological data were collected using a VantagePro 2 weather system (Davis Instruments, Inc.). The meteorological system recorded temperature, pressure, wind direction, wind speed, total solar radiation, UV index, precipitation and relative humidity. An instrument trailer containing real-time particle and gas instrumentation, as well the meteorological data acquisition system, was setup $39 \mathrm{~m}$ north of the northernmost barn (Barn 3, refer to Fig. 1) and also served as the main downwind sampling location/receptor based on historical wind data. 


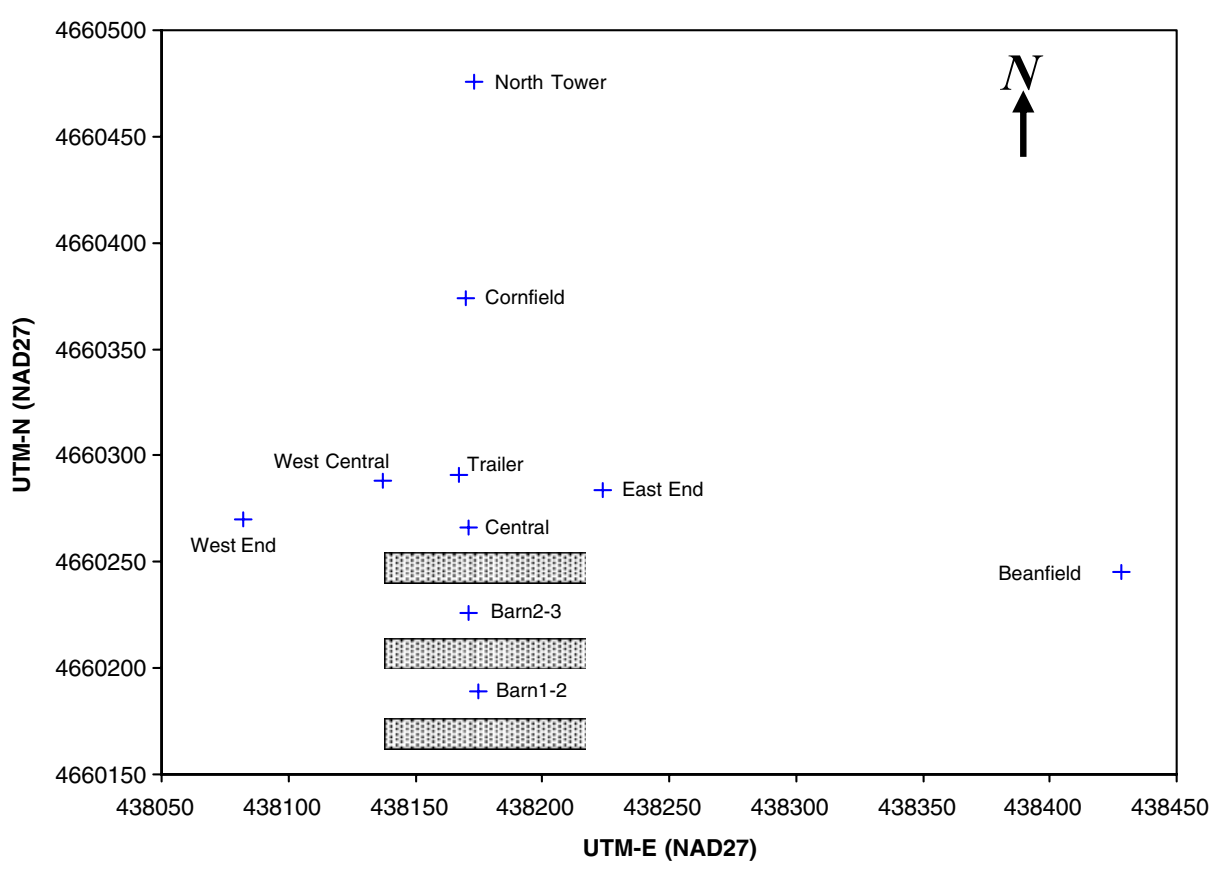

Fig. 1 Site layout showing hog barns and particulate sampling locations, Ames, IA

\subsection{Particle collection and analysis}

Size-fractionated particulate mass concentration data $\left(\mathrm{PM}_{2.5}\right.$ and $\left.\mathrm{PM}_{10}\right)$ at the sample locations were collected on filters using ten MiniVol portable air samplers (AirMetrics, Inc.). The MiniVols' inlets were assembled to sample $\mathrm{PM}_{2.5}$ for the first eight days (August 24 to September 1, 2005) and $\mathrm{PM}_{10}$ for the rest of the test period (September 2-8, 2005). Visual observations of relatively light collections on the $\mathrm{PM}_{2.5}$ background and facilityimpacted filters motivated the switch to the $\mathrm{PM}_{10}$ impactor heads. The samplers' rotameters were calibrated prior to field deployment and operated at actual flow rates of 5.0 liters per minute $\left(\mathrm{L} \min ^{-1}\right)$, with a nominal 23-h sampling time. The particles were collected on preweighed, pre-conditioned 47 millimeter $(\mathrm{mm})$ Teflon filters according to federal protocols (40 CFR 50), which were transported back to USU's Utah Water Research Laboratory (UWRL) after exposure for final weight and concentration determination. Conditioning was at room temperature in a desicator. $(20-40 \% \mathrm{RH})$ The filter weights both pre- and post sampling were measured using a Mettler MT5 microbalance (Mettler Instrument Corp.) to the nearest microgram $(\mu \mathrm{g})$ and the reported filter weights were the average of three separate daily weights within $\pm 2.5 \mu \mathrm{g}$. This uncertainty is roughly equivalent to a minimum system detection level (MDL) of 0.36 micrograms per cubic meter $\left(\mu \mathrm{g} \mathrm{m}^{-3}\right)$.

Chemical characterization of the collected ambient particulate matter involved both realtime and post-test laboratory analyses. Ion chromatography (IC) was used to determine the concentrations of dominant anions and cations from the collected filters. After the filter weights were finalized, the filter ions were extracted with a total of 30 milliliters $(\mathrm{mL})$ of $0.2 \mu \mathrm{m}$ filtered, double-distilled, deionized water (DDW). The Teflon filters were sequentially sonicated with $10 \mathrm{~mL}$ of DDW for $10 \mathrm{~min}$ three times each. The $30 \mathrm{~mL}$ total eluted solution was split into two $15 \mathrm{~mL}$ aliquots: one for anion analysis and one for cation 
analysis. The solutions for cation analysis were additionally spiked with 10 microliters $(\mu \mathrm{L})$ of 0.5 molar $(\mathrm{M}) \mathrm{HCl}$ to prevent the ammonium $\left(\mathrm{NH}_{4}^{+}\right)$from volatilizing as ammonia $\left(\mathrm{NH}_{3}\right)$. The IC system (Dionex, Inc.) consisted of the following equipment: an AS 40 automated sampler, a CD 20 conductivity detector, a GP 40 gradient pump, an ASRS-Ultra II membrane suppressor for anions and a CSRS-Ultra II membrane suppressor for cations, LC 25 chromatography oven, and an IonPac ${ }^{\circledR}$ AS4A-SC $(4 \mathrm{~mm})$ anion column or an IonPac ${ }^{\circledR} \mathrm{CS} 12 \mathrm{~A}$ cation column, depending on the ionic species of interest. For anion analysis, a $195-\mu \mathrm{L}$ injection loop was used in the IC, while for cations analysis, an $80-\mu \mathrm{L}$ injection loop was used. The IC eluent used for anions analysis was a 30 millimolar (mM) sodium hydroxide $(\mathrm{NaOH})$ solution. The eluent used for cation analysis was a $0.15 \mathrm{M}$ sulfuric acid $\left(\mathrm{H}_{2} \mathrm{SO}_{4}\right)$ solution. Standard solutions were prepared from ACS reagent grade salts (Fisher-Scientific) and calibration curves were prepared using concentrations of 0.1 , $0.5,1,5$, and 10 milligrams per liter $\left(\mathrm{mg} \mathrm{L}^{-1}\right)$ or parts per million (ppm). Blank and continuing calibration verification standards $(\mathrm{CCV})$ were tested approximately every 10 samples. Ten percent of the samples were randomly chosen for duplicate analysis to ensure reproducibility.

A Series 5400 Ambient Particulate Carbon Monitor (Rupprecht \& Patashnick Co., Inc.) was assembled in the instrument trailer to characterize organic and inorganic (elemental) particulate carbon (OC and EC, respectively) downwind from the facility. The 5400 is a semi real-time system which provides data at user defined time intervals (every $3 \mathrm{~h}$ for these studies) for organic carbon and total carbon (TC) concentrations $\left(\mu \mathrm{g} \mathrm{m}^{-3}\right)$. The instrument determines carbon concentrations by thermal-carbon dioxide $\left(\mathrm{CO}_{2}\right)$ analysis (R\&P 2004). As recommended by the operating manual (R\&P 2004), the system dwell times and temperatures were set for $600 \mathrm{~s}$ at $275^{\circ} \mathrm{C}$ and for $360 \mathrm{~s}$ at $750^{\circ} \mathrm{C}$ for $\mathrm{OC}$ and $\mathrm{TC}$ determination, respectively. The EC fraction is determined as the difference between the TC and $\mathrm{OC}$ concentrations. Flow and $\mathrm{CO}_{2}$ response calibrations were performed prior to field deployment and zero air and $\mathrm{CO}_{2}$ span audits were performed on-site every third day using commercially-purchased calibration gases (Scott Specialty Gases, Inc.). The instrument was set to operate at $16.7 \mathrm{~L} \mathrm{~min}^{-1}$ and the size fractionation head $\left(\mathrm{PM}_{10}\right.$ or $\left.\mathrm{PM}_{2.5}\right)$ was set in conjunction with MiniVols' inlets. Because the method measures only the carbon part of the organic fraction, one must compensate for oxygen-containing and other functional groups. The $\mathrm{CO}_{2}$ based concentrations were multiplied by a correction factor, $R_{\mathrm{oc}}$, of 2.1 recommended for non-urban organic aerosols (Malm and Hand 2005).

Ambient particulate size analyses were also performed using six Model 9722 Ambient Aerosol Particulate Profilers (MetOne, Inc.) at several of the same locations as the filterbased samplers. The 9722 are real-time, optical particle counters (OPCs) which simultaneously measure particle number concentrations using laser diode technology into eight user-defined size ranges between $0.3 \mu \mathrm{m}$ and $10 \mu \mathrm{m}$ over 20 second time periods. The system samples at a nominal flow rate of $1 \mathrm{Lmin}^{-1}$; however, the systems' flow paths are plumbed such that they operate with a 2:1 dilution rate to allow for sampling of high concentration particulate fields. The lower cut off size for the sampling ranges were set to $0.3,0.5,0.7,1,2,2.5,5$ and $10 \mu \mathrm{m}$. The systems' were factory calibrated immediately prior to field use. Data were archived to central data acquisition system via individual radio frequency channels.

An aerosol mass spectrometer (AMS; Aerodyne, Inc.) was also stationed inside the instrument trailer to quantify and characterize sub-micron organic and inorganic ions. The AMS is made up of three differentially pumped chambers: the sampling chamber, the sizing chamber, and the analysis chamber. The sample is brought into the instrument by the difference in pressure through an aerodynamic focusing lens (Liu et al. 1995). Particles in 
the range of 50-700 nanometers $(\mathrm{nm})$ are focused with almost $100 \%$ efficiency with particles above and below that size range focused with less efficiency. As the AMS system essentially characterizes particulate matter less than or equal to $1.0 \mu \mathrm{m}$, it approximates a $\mathrm{PM}_{1}$ measurement. However, this is dependent on composition as some components, especially metals and elemental carbon are not detected by this method. In addition, the AMS detects the full organic matter (OM) composition rather than simply the carbon fraction. The particles within the chambers are accelerated through supersonic expansion to a velocity proportional to their size. Particles continue onto an oven where the nonrefractory components are flash vaporized at $600-700^{\circ} \mathrm{C}$. The vapors are then subjected to a beam of electrons at 70 electron volts $(\mathrm{eV})$ for ionization before being scanned by a quadrupole mass spectrometer and detected with an electron multiplier. The instrument can be operated in two modes: (1) the "mass spec" (MS) mode, which obtains chemical speciation for the ensemble particle sample and (2) the "time-of-flight" (ToF) mode which obtains particle size distributions associated with specific chemical species. A more detailed explanation of the principles and capabilities of the AMS can be found in Jayne et al. (2000) and Jimenez et al. (2003).

The AMS was operated on-site continuously from August 29 to September 4, 2005. Particulate samples were withdrawn from the ambient air through 0.25-in., outer diameter (o.d.) copper tubing at a flow rate of about 1.2 cubic centimeters per second $\left(\mathrm{cm}^{3} \mathrm{~s}^{-1}\right)$. The AMS time averaging interval was set to 1 hour due to the low concentrations of the submicron particles expected at the site. During this time, the AMS alternated between MS and ToF modes of acquisition. Ionization efficiency and size calibrations were performed on-site using ammonium nitrate $\left(\mathrm{NH}_{4} \mathrm{NO}_{3}\right)$ and commercially-purchased polystyrene latex (PSL) spheres. The former were used in the computation of the mass concentration calibrations, while the latter were for size distribution quantification.

\section{Results and discussion}

\subsection{Observed meteorology}

Figure 2 shows the hourly averaged wind directions for the entire study period as measured by the Vantage Pro on the top of the instrument trailer ( $5 \mathrm{~m}$ height). As can be seen, the wind blew from the optimum direction in relationship to the established sampling array, the southern quadrant $\left(135-225^{\circ}\right)$, only about $37 \%$ of the time. Furthermore, calm or nondetectable winds were observed $14 \%$ of the time. The wind directions were most variable during the early $\left(\mathrm{PM}_{2.5}\right)$ portions of the study period, but as can be seen, were rarely from the desired southern quadrant. Similarly, the first two days of the $\mathrm{PM}_{10}$ studies were characterized by primarily northern winds. Southern winds became more typical during the final few days of the study. Therefore, the data were divided into three analysis periods based on sample type and prevailing wind direction: (1) $\mathrm{PM}_{2.5}$ variable winds (north \& south), August 24-31, 2005, (2) $\mathrm{PM}_{10}$ upwind (north winds), September 1-2, 2005, and (3) $\mathrm{PM}_{10}$ downwind (south winds), September 3-8, 2005. Unless otherwise noted, the Beanfield sampling location (refer to Fig. 1) was found to be most consistently crosswind to the presumed particulate source (the barns) and considered as the ambient background location.

Atmospheric pressures were stable for most of the campaign. A $4.1 \mathrm{~mm}$ pressure drop was observed over five hours on August 25-26, 2005 and a $3 \mathrm{~mm}$ pressure increase was observed over a one hour period on September 5, 2005. Ambient temperature averaged 21.1 


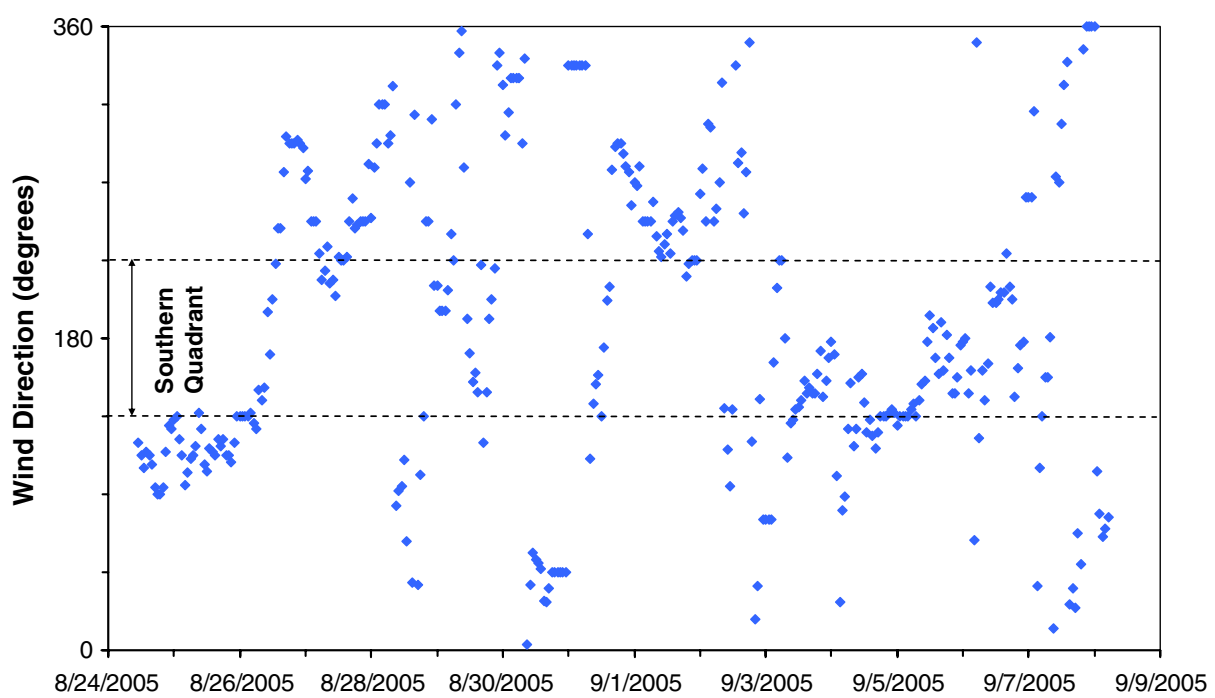

Fig. 2 Observed hourly averaged wind directions (North $=0^{\circ}$ )

degrees Celsius $\left({ }^{\circ} \mathrm{C}\right)$, the highest hourly temperature observed was $30.5^{\circ} \mathrm{C}$, and the lowest hourly temperature observed was $10.1^{\circ} \mathrm{C}$. The average barometric pressure was $738.3 \mathrm{~mm}$ mercury (mm Hg), with maximum and minimum hourly values of 743.7 and $732.3 \mathrm{~mm} \mathrm{Hg}$, respectively.

\subsection{Particle emissions}

Figure 3 shows the average facility-derived $\mathrm{PM}_{2.5}$ and $\mathrm{PM}_{10}$ concentrations measured by the MiniVol samplers located throughout the study area. The facility-derived particulate concentration refers to a selected receptor's concentration minus the observed local background concentration. The $\mathrm{PM}_{2.5}$ background concentrations during the early phases of the study (August 24-31, $n=8$ ) averaged 13.5 $\pm 3.6 \mu \mathrm{g} \mathrm{m}^{-3}$ and $\mathrm{PM}_{10}$ background concentrations averaged $36.4 \mathrm{\mu g} \mathrm{m}^{-3}$ and $37.9 \pm 6.3 \mu \mathrm{g} \mathrm{m}^{-3}$ for the upwind (September $1-2$, $n=2$ ) and downwind (September 3-8, $n=6$ ) periods, respectively. Unless otherwise noted, all uncertainties reported represent the $95 \%$ confidence interval $(95 \% \mathrm{CI})$ about the average. Furthermore, it should be noted that during the $\mathrm{PM}_{10}$ upwind period, samples were only collected on two days, as such, confidence intervals could not be calculated for that period.

As can be derived from Fig. 3, the facility-derived (downwind-background) $\mathrm{PM}_{2.5}$ concentrations were only slightly above the typical background values. The average $\mathrm{PM}_{2.5}$ concentration attributable to the facility averaged only $1.7 \pm 1.1 \mathrm{\mu g} \mathrm{m}^{-3}$, indicating relatively little emissions of $\mathrm{PM}_{2.5}$-sized particles from deep-pit swine finishing operations. Even though the wind directions during the $\mathrm{PM}_{2.5}$ measurement phase of the described study were variable, the receptors placed between the barns averaged only $1.8 \pm 0.8 \mu \mathrm{g} \mathrm{m}^{-3}$ and $1.6 \pm$ $0.8 \mu \mathrm{g} \mathrm{m}^{-3}$ above background, respectively. Similarly, the $\mathrm{PM}_{10}$ concentrations at most of the receptor locations on the north or upwind days showed little difference above background concentrations. Not unexpectedly, the sampler between Barns 1 and 2 did show an increased concentration an average of $9.2 \mathrm{\mu g} \mathrm{m}^{-3}$ above background levels (over two daily periods).

However, on days when the winds were predominantly southern (September 3-8) most of the receptors were downwind of the facilities. The $\mathrm{PM}_{10}$ attributable to the local swine 


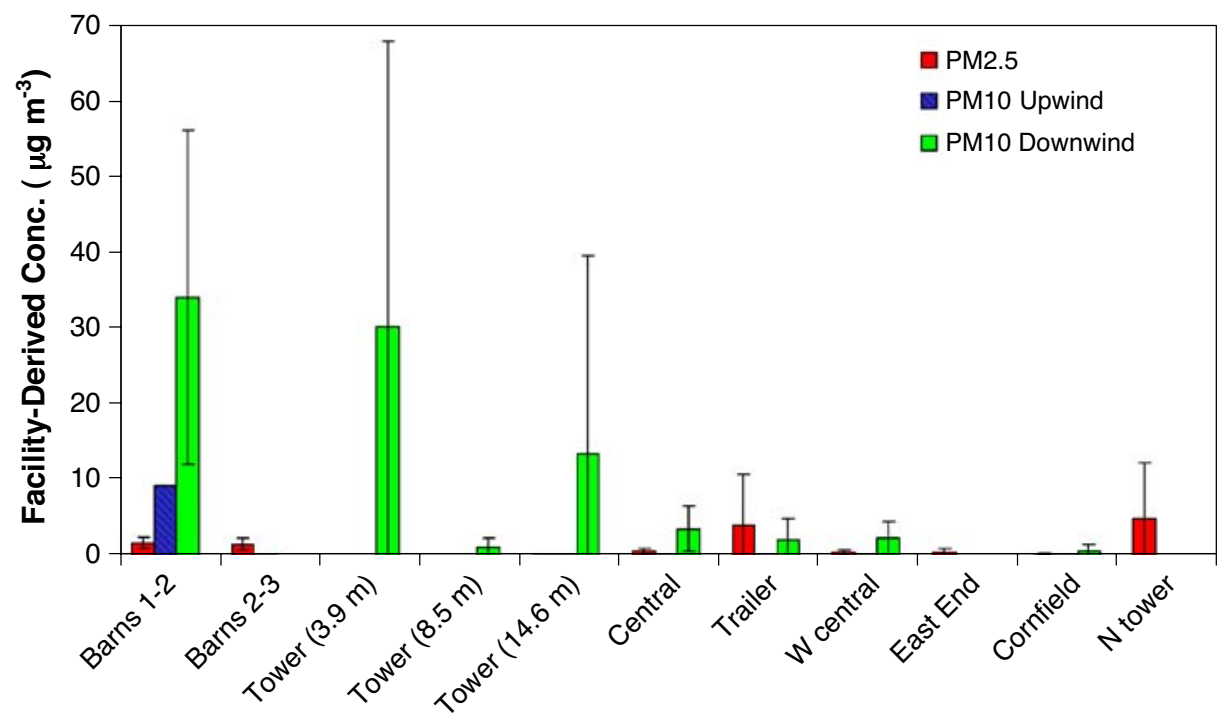

Fig. 3 Facility-derived $\mathrm{PM}_{2.5}$ and $\mathrm{PM}_{10}$ concentrations measured by MiniVol samplers around the deep-pit swine operation (error bars represent the 95\% confidence interval about the mean). Missing data indicate periods when no samples collected due to sampler availability or system error

operation became more significant: $5.8 \pm 2.9 \mu \mathrm{g} \mathrm{m}^{-3}$ above background averaged across all of the receptor locations. As can be seen from Figs. 1 and 3 , the facility-derived $\mathrm{PM}_{10}$ decreased as the distance from the barns increased. The near-source, ground-level $\mathrm{PM}_{10}$ attributable to the barns (Barns 1-2, Tower $3.9 \mathrm{~m}$, Central, and Trailer receptors) averaged $10.3 \pm 5.0 \mu \mathrm{g} \mathrm{m}^{-3}$. The highest and most significant concentrations above background were observed at the inter-barn locations $\left(25.1 \pm 13.2 \mu \mathrm{g} \mathrm{m}^{-3}\right)$.

The AMS found $\mathrm{PM}_{1}$ mass concentrations of $0.91 \pm 0.14 \mu \mathrm{g} \mathrm{m}^{-3}$ and $1.02 \pm 0.19 \mu \mathrm{g} \mathrm{m}^{-3}$, for the previously discussed $\mathrm{PM}_{2.5}$ and upwind $\mathrm{PM}_{10}$ periods, indicating a statistically consistent background concentration of the submicron $(\leq 1 \mu \mathrm{m})$ particulate matter. The average AMS $\mathrm{PM}_{1}$ mass concentration during the downwind study period was $2.47 \pm$ $0.28 \mu \mathrm{g} \mathrm{m}^{-3}$, indicating a small contribution of $\mathrm{PM}_{1}$ material from the observed facility. Comparing these values with the averaged filter-based ambient $\mathrm{PM}_{2.5}$ and $\mathrm{PM}_{10}$ concentrations measured at the sampling trailer, the $\mathrm{PM}_{1}$ made up $6.6 \%$ and $4.1 \%$ of the upwind or background $\mathrm{PM}_{2.5}$ and $\mathrm{PM}_{10}$, respectively. During the facility-impacted (downwind) measurements, the ultra-fine particle concentrations increased (Fig. 4) as did the larger particle sizes. However, the $\mathrm{PM}_{1}$ fractionally made up around the same percentage $(5.9 \%)$ of the $\mathrm{PM}_{10}$ mass as during the upwind periods.

\subsection{Particle composition}

The chemical compositions of the $\mathrm{PM}_{2.5}$ and $\mathrm{PM}_{10}$ as determined from the filter-based AirMetrics' sampler located at the air quality trailer are shown in Table 1. Approximately $48 \%$ and $33 \%$, of the upwind $\left(\mathrm{PM}_{2.5}\right.$ and $\left.\mathrm{PM}_{10}\right)$ and downwind $\left(\mathrm{PM}_{10}\right)$ filter mass, respectively, were unidentified using the employed analytical techniques. Although not enough samples were collected for statistical analysis of the upwind $\mathrm{PM}_{10}$ data, of the identified species only calcium $\left(\mathrm{Ca}^{+2}\right)$ concentrations appeared to be different between the upwind $\mathrm{PM}_{2.5}$ and $\mathrm{PM}_{10}$ samples. Shacklette and Boerngen (1984) identified the crustal 
Fig. $4 \mathrm{PM}_{1}$ mass concentration as measured by the Aerosol Mass Spectrometer (AMS) at the air quality sampling trailer $39 \mathrm{~m}$ north of Barn 3

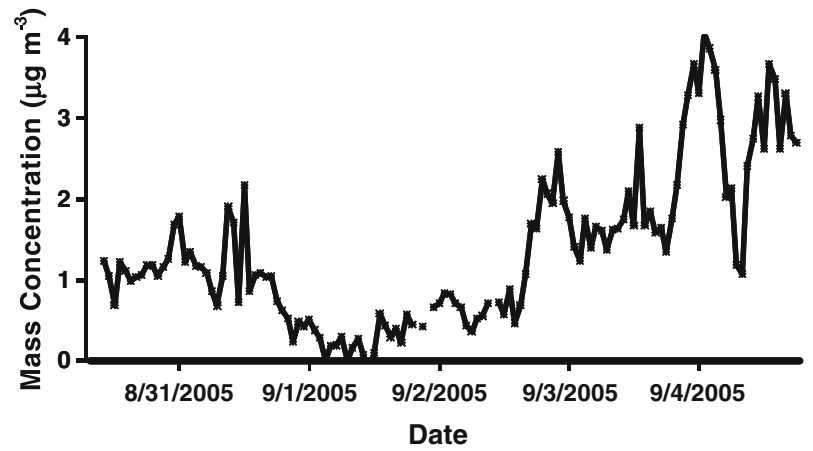

surfaces of north-central Iowa as abundant in calcium. Particulate-bound concentrations of fluoride $\left(\mathrm{F}^{-}\right)$, chloride $\left(\mathrm{Cl}^{-}\right)$, sodium $\left(\mathrm{Na}^{+}\right)$, and magnesium $\left(\mathrm{Mg}^{+2}\right)$ showed no statistical difference between upwind and downwind (source-impacted) conditions, indicating these species are likely associated with local or regional background particulate. It is of further interest to note the observed abundance of fluoride in the background particulate mass $\left(1.04 \pm 0.31 \mu \mathrm{g} \mathrm{m}^{-3}\right.$, over all trailer samples). Shacklette and Boerngen (1984) showed regional Iowa soil elevated in fluoride concentrations which could explain the relatively high fluoride levels. Sulfate $\left(\mathrm{SO}_{4}^{-2}\right)$, nitrate $\left(\mathrm{NO}_{3}^{-}\right)$, ammonium $\left(\mathrm{NH}_{4}^{+}\right)$, calcium, organic carbon (OC), and elemental carbon (EC) all showed statistical $(95 \% \mathrm{CI})$ concentration increases when impacted by the swine facilities. The $\mathrm{OC}$ was consistently the largest single, identified component of the $\mathrm{PM}_{10}$ concentrations measured at the sampling trailer $(\approx 20 \%)$. The OC component increased by a factor of approximately three from $2.53 \pm 0.48$ to $7.56 \pm$ $2.65 \mu \mathrm{g} \mathrm{m}^{-3}$ between periods when the sampling trailer was upwind and downwind of the barns. The EC component showed approximately a four fold increase between nonimpacted and impacted conditions: $0.40 \pm 0.13$ to $1.76 \pm 0.76 \mathrm{\mu g} \mathrm{m}^{-3}$, respectively. However, the EC contribution accounted for only $\approx 3-5 \%$ of the particle mass.

The AMS-measured $\mathrm{PM}_{1}$ composition is shown in Table 2. Due to equipment malfunctions the AMS data contained gaps at the beginning and end of the period while the MiniVol instruments sampled. The $\mathrm{PM}_{1}$ system found measurable concentrations of $\mathrm{SO}_{4}^{-2}, \mathrm{NO}_{3}^{-}, \mathrm{NH}_{4}^{+}$, and $\mathrm{OM}$. All but $\mathrm{NO}_{3}^{-}$show statistically significant concentration increases when the trailer was downwind versus upwind of the swine barns $(\approx 2-3 \times)$. As with the $\mathrm{PM}_{10}$, the $\mathrm{OC}$ was the largest component of the $\mathrm{PM}_{1}$ and showed similar behavior depending on the wind direction (see Fig. 5). As can be seen, the $\mathrm{PM}_{1} \mathrm{OM}$ concentration was on an order of magnitude less than the $\mathrm{PM}_{10}$ OC concentrations.

In order to examine one possible reason for the unknown mass percentages previously mentioned, an ion mass balance was performed for the analyzed AMS and trailer aerosols (Fig. 6). The total cations measured were found to be in excess for all observed samples, regardless of wind direction or particle size classification. However, as can be seen, the deficit was only statistically significant $(95 \%$ CI) for the downwind, barns-impacted conditions. Recall, there were an insufficient number of $\mathrm{PM}_{10}$ upwind samples to determine confidence intervals. It is suspected that much of the ion deficit could be the result of carbonate $\left(\mathrm{CO}_{3}^{-}\right)$, which was not resolved with the employed analytical techniques. The presence of abundant particle-based $\mathrm{Ca}^{+2}$ and $\mathrm{Mg}^{+2}$ further suggests the presence of carbonates, which are often associated with soil-derived particles (Krivacsy and Molnar 1998; Ocsay et al. 2006). An additional possibility for the mass deficit could be the result of unquantified crustal materials. During the field campaign, the LiDAR measurements of 


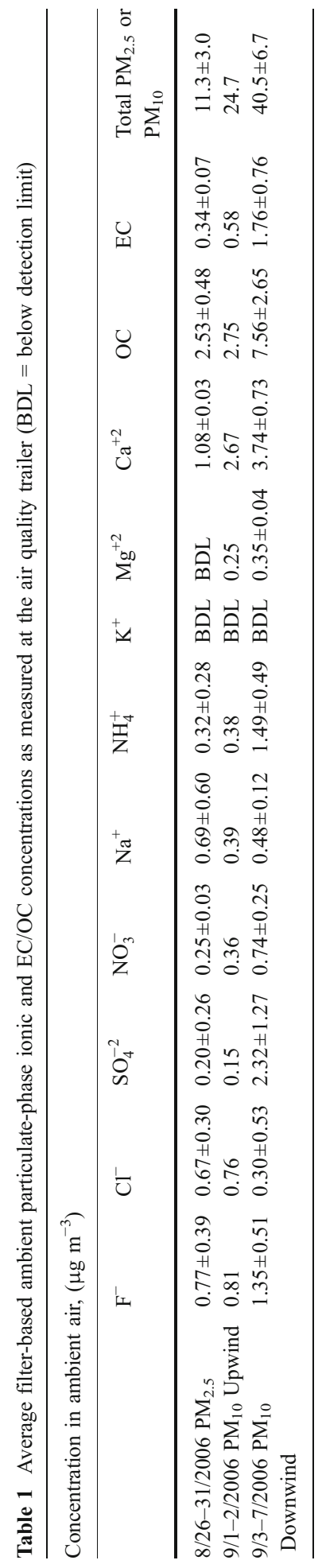


Table 2 Average particle-phase ionic and organic carbon concentrations measured by the AMS $\left(\mathrm{PM}_{1}\right)$

Concentration in ambient air, $\left(\mu \mathrm{g} \mathrm{m}^{-3}\right)$

\begin{tabular}{llllll}
\hline & $\mathrm{SO}_{4}^{-2}$ & $\mathrm{NO}_{3}^{-}$ & $\mathrm{NH}_{4}^{+}$ & $\mathrm{OC}$ & Total AMS PM \\
\hline 8/29-31/2006 & $0.07 \pm 0.02$ & $0.04 \pm 0.01$ & $0.06 \pm 0.02$ & $0.38 \pm 0.07$ & $0.91 \pm 0.14$ \\
9/1-2/2006 (upwind) & $0.03 \pm 0.01$ & $0.02 \pm 0.01$ & $0.03 \pm 0.01$ & $0.61 \pm 0.14$ & $1.02 \pm 0.19$ \\
9/3-5/06 (downwind) & $0.12 \pm 0.02$ & $0.04 \pm 0.01$ & $0.12 \pm 0.03$ & $1.34 \pm 0.11$ & $2.47 \pm 0.28$ \\
\hline
\end{tabular}

Zavyalov et al. (2006) observed several instances of plumes from the nearby gravel road dispersing over the various sample locations. This happened on 2 days and due to calm winds, affected all of the samplers.

\subsection{Particle distributions}

The numerical particle size distributions at the trailer location, as measured by the MetOne OPCs, for upwind and downwind periods can be seen in Fig. 7. As can be seen, both the background and barns-impacted distributions showed strong bimodal distributions. The observed bimodal curve is similar in shape and modal locations as those reported by Schneider et al. (2001) for upwind and inside an experimental piggery. However, the number concentrations reported here were more in line with Schneider's reported upwind values, especially for particles less than approximately $1.0 \mu \mathrm{m}$ in diameter. A large particle mode appeared centered around $2.5 \mu \mathrm{m}$ and a fine (accumulation) mode was evident somewhere below the OPCs' minimum quantified diameter $(<0.3 \mu \mathrm{m})$. The barns-impacted (downwind) average number distribution showed a trend for increased numbers of supermicron particles $(>1 \mu \mathrm{m})$ compared to the non-impacted (upwind) number distributions, but as shown in Fig. 7, the difference was not statistically significant at the $95 \%$ confidence level. As shown, this was due to the relatively large uncertainties associated with the background distributions. The average count mean diameters (CMDs)

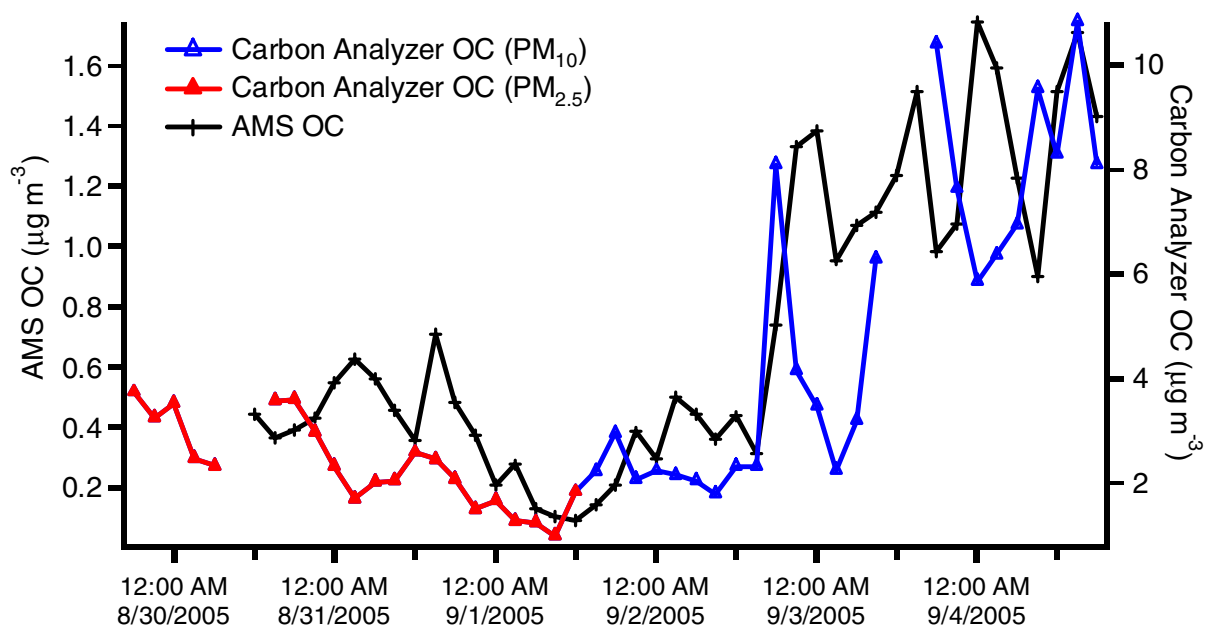

Date and Time

Fig. 5 Three hour average AMS organic carbon concentration compared to EC/OC $\mathrm{PM}_{2.5}$ and $\mathrm{PM}_{10}$ organic carbon concentrations 

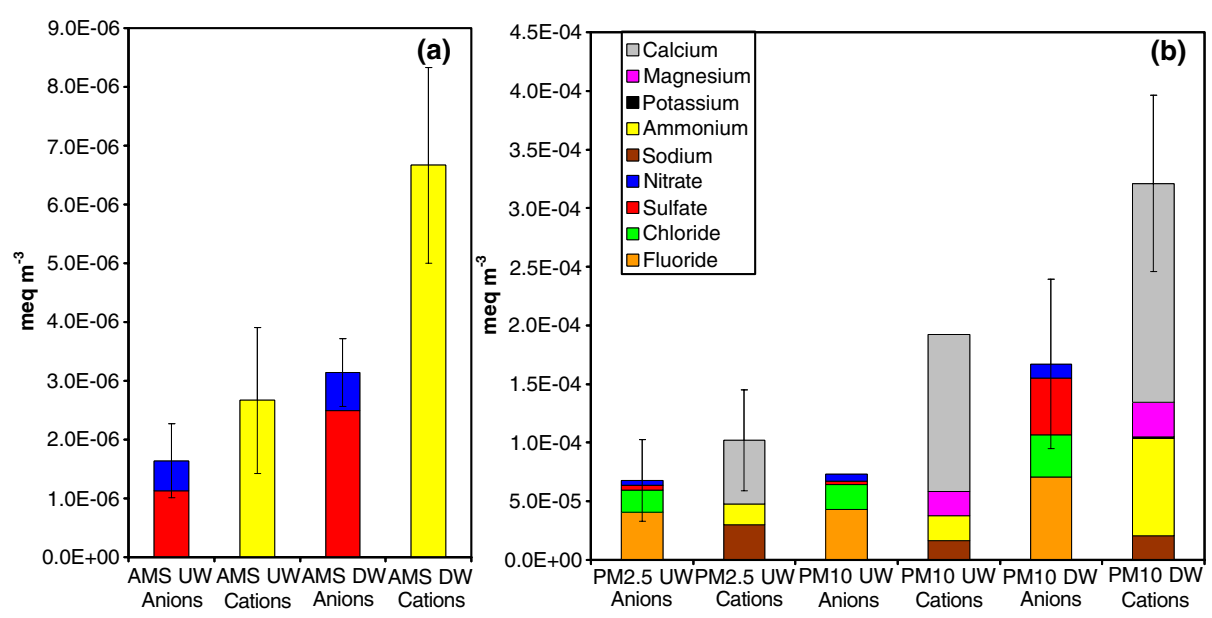

Fig. 6 Particle ion balance of AMS (a) and trailer $\mathrm{PM}_{2.5} / \mathrm{PM}_{10}$ (b) measurements

for the south and north wind periods were found to be similar, yet statistically different at $0.46 \pm 0.01 \mu \mathrm{m}$ and $0.43 \pm 0.01 \mu \mathrm{m}$, respectively.

Size fractionated mass distributions were obtained from the particle counts using the average density of the particles derived by combining the number and AirMetrics' mass concentrations and assuming uniform density throughout the entire size range following the procedure outlined by Hinds (1999). The calculated particulate density of 2.15 grams per cubic centimeter $\left(\mathrm{g} \mathrm{cm}^{-3}\right)$ agrees well with densities from atmospheric aerosol databases (Jursa 1985; Hess et al. 1998). As with the number distributions, bimodal distributions were observed and the downwind and upwind periods did not show statistically different mass distributions (Fig. 8). However, the larger particle size range (coarse mode) did show higher average concentrations. As can also be seen in Fig. 8, the modal diameters are not apparent, but a minimum mass diameter was observed around $0.8 \mu \mathrm{m}$. The mass mean diameters (MMDs) for the south and north wind periods were found to be $5.14 \pm 0.11 \mu \mathrm{m}$ and $4.52 \pm$ $0.16 \mu \mathrm{m}$, respectively. The increase in MMD during south wind periods is consistent with observed particulate impacts from the swine facilities.

The mass distributions of the individual chemical species measured by the AMS are shown in Fig. 9 with respect to vacuum aerodynamic diameter $\left(D_{\mathrm{va}}\right)$. This is the aerodynamic diameter measured under the free-molecular regime. During the upwind

Fig. 7 Numerical particle size distributions as measured by the trailer OPC during upwind (background) and downwind (barns-impacted) periods

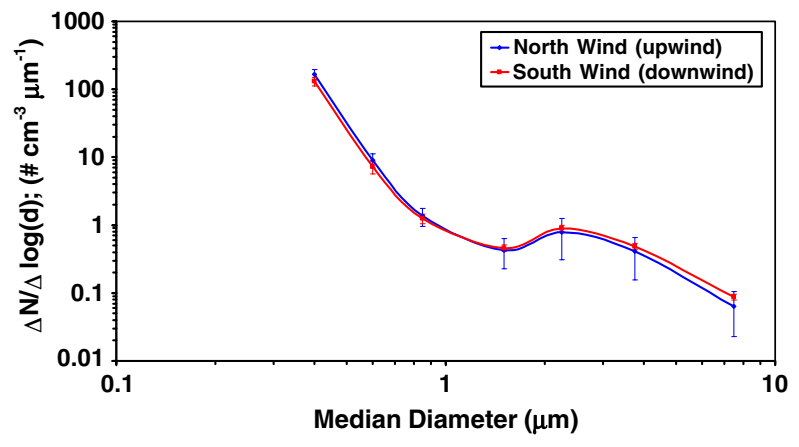


Fig. 8 Particle mass distributions as measured by the trailer OPC during upwind (background) and downwind (barns-impacted) periods

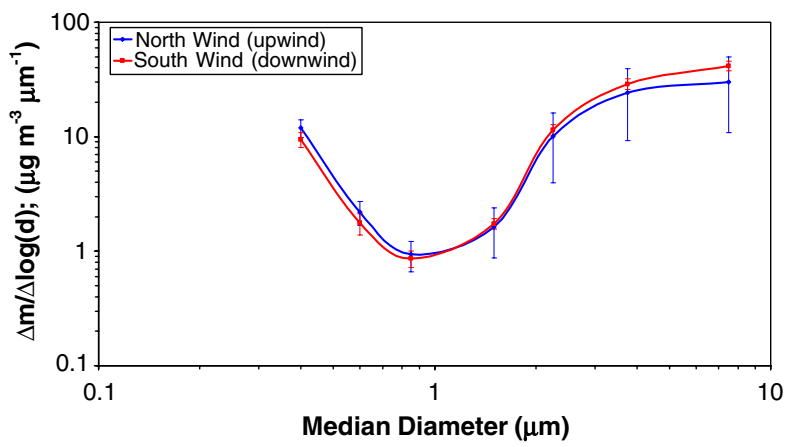

periods sulfate was found to be the dominant mass species, followed by OM. During downwind periods OM was the only dominant species detected by the AMS.

\section{Summary}

Primary particulate matter was a minor pollutant emitted from the examined swine finishing facility, adding $\sim 15 \%$ to the prevailing background levels of $\mathrm{PM}_{10}$ and $\sim 12 \%$ to the background $\mathrm{PM}_{2.5}$. Filter-based, AirMetrics' MiniVol impactor samples found that the general area around the facility showed an increase in $\mathrm{PM}_{10}$ of $5.8 \pm 2.9 \mu \mathrm{g} \mathrm{m}^{-3}$ above background levels $\left(\approx 37 \mu \mathrm{g} \mathrm{m}^{-3}\right)$, although in the area between the barns the $\mathrm{PM}_{10}$ was found to be $25.1 \pm$ $13.2 \mu \mathrm{g} \mathrm{m}^{-3}$ above background. Local $\mathrm{PM}_{2.5}$ attributable to the facility was found to be increased by an average of $1.7 \pm 1.1 \mu \mathrm{g} \mathrm{m}^{-3}$, relative to background $\mathrm{PM}_{2.5}$ concentrations $\left(\approx 14 \mu \mathrm{g} \mathrm{m}^{-3}\right)$. Interestingly, the areas between the barns showed essentially the same above background concentrations as the receptors located further from the barns. An aerosol mass

Fig. 9 Average AMS total and composition-specific particle size distributions for background (north wind) and barns-impacted (south wind) periods

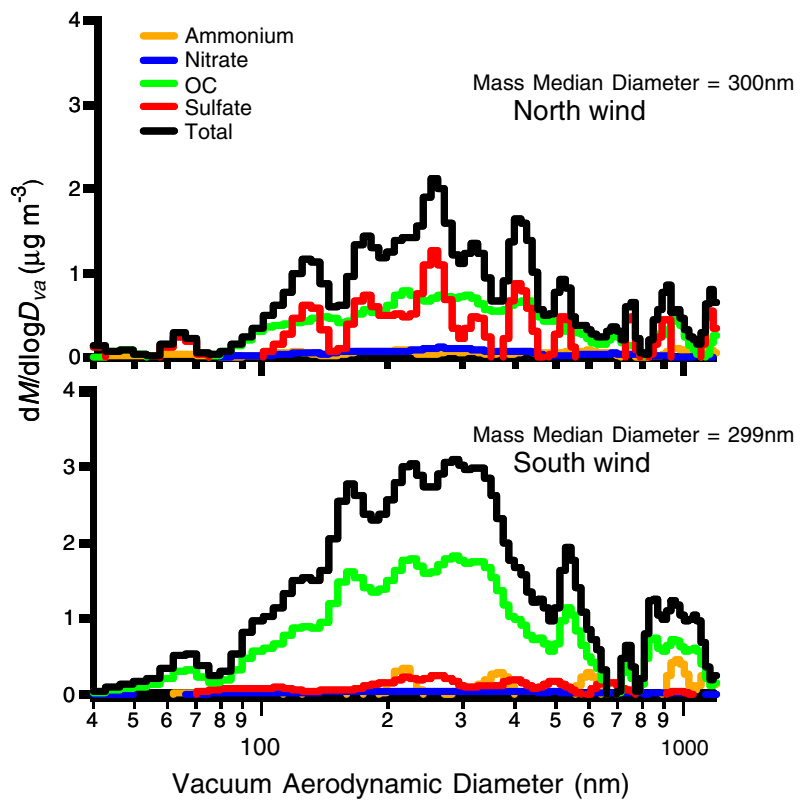


spectrometer measured ambient $\mathrm{PM}_{1}$ at a single location, the air quality trailer, located approximately $39 \mathrm{~m}$ north of the northern most barn (refer to Fig. 1) and reported upwind (non-facility impacted) and downwind $\mathrm{PM}_{1}$ concentrations of $1.0 \pm 0.2 \mu \mathrm{g} \mathrm{m}{ }^{-3}$ and of $2.5 \pm$ $0.3 \mu \mathrm{g} \mathrm{m}^{-3}$, respectively. Optical particle counter (OPC) analysis of the numerical size distributions showed a strong bimodal distribution with maximums around $2.5 \mu \mathrm{m}$ and somewhere below the OPCs' minimum quantified diameter $(<0.3 \mu \mathrm{m})$. The average distributions showed increased numbers of coarse particles during barns-impacted periods, but the differences did not become statistically significant until the $68 \%$ confidence level (approximately one standard deviation).

Chemical composition of the aerosols at the air quality trailer was quantified by ion chromatographic analysis of the impactor filters, with the use of a semi-real time EC/OC analyzer (configured to match the size fractionation of the MiniVol impactors), and via the AMS. For the $\mathrm{PM}_{10}$, sulfate $\left(\mathrm{SO}_{4}^{-2}\right)$, nitrate $\left(\mathrm{NO}_{3}^{-}\right)$, ammonium $\left(\mathrm{NH}_{4}^{+}\right)$, calcium $\left(\mathrm{Ca}^{+2}\right)$, organic carbon (OC), and elemental carbon (EC) all showed statistically significant concentration increases when the wind direction was from the pig barns to the samplers (south winds). Particulate magnesium $\left(\mathrm{Mg}^{+2}\right)$, potassium $\left(\mathrm{K}^{+}\right)$, sodium $\left(\mathrm{Na}^{+}\right)$, fluoride, $\left(\mathrm{F}^{-}\right)$, and chloride $\left(\mathrm{Cl}^{-}\right)$showed no statistical difference based on wind direction. An excess of cations to anions was observed which may be attributed to the fact that carbonate $\left(\mathrm{CO}_{3}^{-2}\right)$ was not detected with the utilized analytical scheme. The AMS $\mathrm{PM}_{1}$ chemical speciation showed similar species increases as with the filter-based measurements, with the exception of $\mathrm{NO}_{3}^{-}$, which was not significantly different between the upwind and downwind samples and $\mathrm{Ca}^{+2}$ which is not quantified by the AMS. Organic carbon was the major constituent of the barn-impacted particulate matter in both sub-micron and coarse size ranges, accounting for approximately $54 \%$ and $20 \%$ of the observed mass, respectively.

Acknowledgments The authors would like to thank the following individuals and organizations, without whose help this project could not have proceeded:

U.S. Dept of Agriculture (USDA Agreement number 58-3625-4-121), Dr. Jerry Hatfield, Agricultural Research Services; Utah State University (USU); Space Dynamics Laboratory, USU Research Foundation; Utah Water Research Laboratory; and Schwartz Hog Farm, Ames, IA. Thanks also go to James Allan for developing the software used for analysis of the AMS data. Any opinions, findings, conclusions, or recommendations expressed in this publication are those of the authors and do not necessarily reflect the view of the U.S. Department of Agriculture.

\section{References}

Alfaro, S.C., Laurent, G.: Modeling mineral aerosol production by wind erosion: emission intensities and aerosol size distributions in source areas. J. Geophys. Res. 106, 18075-18084 (2001)

Aneja, V.P., Schlesinger, W.H., Niyogi, D., Jennings, G., Gilliam, W., Knighton, R.E., Duke, C.S., Blunden, J., Krishnan, S.: Emerging national research needs for agricultural air quality. EOS, Transactions, American Geophysical Union 87(3), 25-36 (2006) January 17, 2006

Auvermann, B., Bottcher, R., Heber, A., Meyer, D., Parnell Jr, C.B., Shaw, B., Worley, J.: Particulate matter emissions from animal feeding operations: White paper. National Center for Manure and Animal Waste Management, St. Joseph, Michigan (2006)

Barber, E.M., Dawson, J.R., Battams, V.A., Nicol, R.A.C.: Spatial variability of airborne and settled dust in a piggery. J. Agric. Eng. Res. 50, 107-127 (1991)

Crichlow, E.C., Yoshida, K., Wallace, K.: Dust in a riding stable. Equine Vet. J. 12, 185-188 (1980)

Dockery, D.W., Pope, C.A., Xu, X., Spengler, J.D., Ware, J.H., Fay, M.E., Ferris, B.G., Speizer, F.E.: Mortality risks of air pollution. A prospective cohort study. N. Engl. J. Med. 329, 1753-1759 (1993) 
Heber, A.J., Ni, J.Q., Lim, T.T., Chervil, R., Tao, P.C., Jacobson, L.D., Hoff, S.J., Zhang, Y., Koziel, J., Beasley, D.S.: Air pollutant emissions from two high-rise layer barns in Indiana, Paper 05-A-1368, presented at the 2005 Annual Convention and Exhibition of the Air \& Waste Management Association, Minneapolis, MN, June 21-24, 2005. Air \& Waste Management Association, One Gateway Center, 3rd Floor, 420 Duquesne Blvd., Pittsburg, PA 15222-1435, USA (2005)

Hess, M., Koepke, P., Schult, I.: Optical proerties of aerosols and clouds: The software package OPAC. Bull. Am. Meteorol. Soc. 79, 831-844 (1998)

Hinds, W.C.: Aerosol Technology_Properties, Behavior and Measurement of Airborne Particles, pp. 75110. Wiley, New York, NY, USA (1999)

Hoff, S.J, Zelle, B.C., Huebner, M.A., Gralapp, A.K., Bundy, D.S., Jacobson, L.D., Heber, A.J., Ni, J., Koziel, J.A., Sweeten, J.M., Zhang, Y., Beasley, D.B.: $\mathrm{NH}_{3}, \mathrm{H}_{2} \mathrm{~S}, \mathrm{CO}_{2}$, PM, and odor animal emission data from the six-state (APECAB) project: Swine deep-pit finishing buildings in Iowa, Paper 05-A-648, presented at the 2005 Annual Convention and Exhibition of the Air \& Waste Management Association, Minneapolis, MN, June 21-24, 2005. Air \& Waste Management Association, One Gateway Center, 3rd Floor, 420 Duquesne Blvd., Pittsburg, PA 15222-1435, USA (2005)

Hughes, L.S., Allen, J.O., Kleeman, M.J., Johnson, R.J., Cass, G.R., Gross, D.S., Gard, E.E., Gälli, M.E., Morrical, B.D., Fergenson, D.P., Dienes, T., Noble, C.A., Liu, D.Y., Silva, P.J., Prather, K.A.: Size and composition distribution of atmospheric particles in southern California. Environ. Sci. Technol. 33, 3506-3515 (1999)

Jayne, J.T., Leard, D.C., Zhang, X., Davidovits, P., Smith, K.A., Kolb, C.E., Worsnop, D.R.: Development of an aerosol mass spectrometer for size and composition analysis of submicron particles. Aerosol Sci Tech 33, 49-70 (2000)

Jimenez, J.L., Jayne, J.T., Shi, Q., Kolb, C.E., Worsnop, D.R., Yourshaw, I., Seinfeld, J.H., Flagan, R.C., Zhang, X., Smith, K.A., Morris, J., Davidovits, P.: Ambient aerosol sampling with an aerosol mass spectrometer. J Geophys Res-Atmospheres 108(D7), 8425 (2003)

Jursa, A.S.: Handbook of Geophysics and Space Environment. Air Force Geophysics Laboratory (1985)

Krivacsy, Z., Molnar, A.: Size distributions of ions in atmospheric aerosols. Atmos. Res. 46(3), 279-291 (1998)

Lammel, G., Schneider, F., Brugemann, E., Gnauk, T., Rohrl, A., Wieser, P.: Aerosols emitted from a livestock farm in southern Germany. Water, Air, and Soil Pollution, 154, 313-330 (2004)

Liu, P., Ziemann, P.J., Kittelson, D.B., McMurry, P.H.: Generating particle beams of controlled dimensions and divergence: Experimental evaluation of particle motion in aerodynamic lenses and nozzle expansions. Aerosol Sci Tech 22, 314-324 (1995)

Malm, W.C., Hand, J.L.: Review of the IMPROVE equation for estimating ambient light extinction coefficients. IMPROVE Newsletter 14(2), 8 (2005)

Martin, R.S., Moore, K., Doshi, V.: Determination of particle $\left(\mathrm{PM}_{10}\right.$ and $\left.\mathrm{PM}_{2.5}\right)$ and gas-phase ammonia $\left(\mathrm{NH}_{3}\right)$ emissions from a deep-pit swine operation using arrayed field measurements and inverse Gaussian plume modeling. In: Viney, P.A. et al. (Eds), Proceedings: Workshop on Agricultural Air Quality: State of the Science. Department of Communication Services, Campus Box 7603, North Carolina State University, Raleigh, NC 27695-7603, USA (2006a)

Martin, R.S., Moore, K., Doshi, V.: Dairy-Related Emissions of Ammonia and Particulate Matter and Their Influence on Air Quality in Utah's and Idaho's Cache Valley, presented at the Western Dairy Air Quality Symposium, Las Vegas, NV, March 21-22, 2006. Western States Dairy Producers Trade Association, 1315 K Street, Modesto, CA 95354, USA (2006b)

Müller, W., Wieser, P.: Dust and microbial emissions from animal production. In: Strauch, D. (ed.) Animal production and environmental health, pp. 47-90. Elsevier, Amsterdam, The Netherlands (1987)

Nilsson, C.: Dust investigations in pig houses, Report 25, Department of Farm Buildings, Swedish University of Agricultural Sciences, Lund, Sweden (1982)

Ocsay, R., Salma, I., Wang, W., Maenhaut, W.: Characterization and diurnal variation of size-resolved inorganic water-soluble ions at a rural background site. J. Environ. Monit. 8, 300-306 (2006)

R\&P: Operating Manual: Series 5400 Ambient carbon particle monitor, Revision B, Part Number 42-003030. Rupprecht and Patashnick Co., Inc., 25 Corporate Circle, Albany, NY (2004)

Rogge, W.F., Mazurek, M.A., Hildemann, L.M., Cass, G.R., Simoneit, B.R.T.: Quantification of urban organic aerosols at a molecular level: identification, abundance and seasonal variation. Atmos. Environ. 27A, 1309-1330 (1993)

Schmidt, D.R., Jacobson, L.D., Janni, K.A.: Continuous monitoring of ammonia, hydrogen sulfide and dust emissions from swine, dairy, and poultry barns, Paper 024060, presented at the 2002 American Society of Agricultural Engineers Annual International Meeting, Chicago, IL, July 28-31, 2002. American Society of Agricultural and Biological Engineers, 2950 Niles Road, St. Joseph, MI 49085 (2002) 
Schneider, F.E., Engelhardt, T., Wieser, P.H.: Characterization of aerosol particles from animal husbandry with single particle analytical techniques. Paper 01-4010, presented at 2001 American Society of Agricultural Engineers, Sacramento, CA, July30-August 1, 2001, ASAE, St. Joseph, MI (2001)

Shacklette, H.T., Boerngen, J.G.: Element concentrations in soil and other superficial materials of the conterminous United States. U.S. Geological Survey Professional Paper 1270, U.S. Geological Survey, Alexandria, VA, pp 28, 40 (1984)

Speizer, F.E., Heber, A.J., Stroik, M., Faubion, J.M., Willard, L.H.: Size distribution and identification of aerial dust particles in swine finishing buildings. Trans. ASAE 31, 882-887 (1988)

Takai, H., Pedersen, S., Johnsen, J.O., Metz, J.H.M., Koeramp, P.W.G.G., Uenk, G.H., Phillips, V.R., Holden, M.R., Sneath, R.W., Short, J.L.: Concentrations and emissions of airborne dust in livestock buildings in Northern Europe. J. Agric. Eng. Res. 70, 59-77 (1998)

Turnbull, A.B., Harrison, R.M.: Major component contributions to $\mathrm{PM}_{10}$ composition in the United Kingdom. Atmos. Environ. 34, 3129-3137 (2000)

USDA: Agricultural Air Quality Issues. Cooperative State Research, Education, and Extension Service (CSREES), United States Department of Agricultural, Center for Agricultural Air Quality Engineering and Science (CAAQES), Texas A \& M University, College Station, Texas. Accessed: April 2005. Available: http://www.csrees.usda.gov/nea/nre/in-focus/air-if-issues.html (2006)

U.S. EPA: Animal feeding operations consent agreement and final order. Federal Register Environmental Documents, 70(19), January 21, 2005, OAR-2004-0237, FRL-7864-4. Accessed: June 2006. Available: http://www.epa.gov/fedrgstr/EPA-AIR/2005/January/Day-31/a1536.htm (2005a)

U.S. EPA: SCRAM surface meteorological archived data: 1984-1992, Iowa, IA14933. Technology transfer network, Support center for regulatory atmospheric modeling. Accessed: July 2005. Available: http:// www.epa.gov/scram001/surfacemetdata.htm (2005b)

Wathes, C.M., Holden, M.R., White, R.P., Phillips, V.R.: Concentrations and emission rates of aerial ammonia, nitrous oxide, methane, carbon dioxide, dust and endotoxin in UK broiler and layer houses. Br. Poult. Sci. 38, 14-28 (1997)

Wilkerson, T.D., Bingham, G.E., Zavyalov, V.V., Swasey, J., Hancock, J.J., Crowther, B.G., Cornelsen, S.S., Marchant, C., Cutts, J.N., Huish, D.C., Earl, C.L., Andersen, J.M., Cox, M.L.: AGLITE: A multiwavelength LiDAR for aerosols. In: Viney, P.A. et al. (Eds), Proceedings: Workshop on Agricultural Air Quality: State of the Science. Department of Communication Services, Campus Box 7603, North Carolina State University, Raleigh, NC 27695-7603, USA (2006)

Zavyalov, V., Bingham, G.E., Wilkerson, T.D., Swasey, J., Marchant, C., Rogers, C., Martin, R., Silva, P., Doshi, V.: Characterization of particulate emission from animal feeding operation with three-wavelength Lidar using simultaneous in-situ point measurements as calibration reference sources. In: Viney, P.A. et al. (Eds), Proceedings: Workshop on Agricultural Air Quality: State of the Science. Department of Communication Services, Campus Box 7603, North Carolina State University, Raleigh, NC 276957603, USA (2006) 